Here's another point to ponder. Special interests like wilderness lobbies need only concern themselves with their own objectives and they have no real public accountability at all. Resource agencies are accountable to government and ultimately to the general public with all its special interests. They must consider each individual demand but also the sum of them all.

Wilderness does for us what no other social value can do. We must have it. Not to satisfy the wilderness lobbies alone, for reasons much more vital than that. But wilderness is not free! Ultimately, its value will be measured by how much people are willing to give up to have it.

The general public, and I suspect most wilderness lovers as well, have expectations that the social benefits derived from multiple use resource management will continue indefinitely if not increase over time. If we set more and more areas aside for wilderness, these other expectations must be lowered proportionately. We can't have it both ways.
I believe we should have more wilderness. I believe our society will benefit from having consciously decided to leave some places alone. I am prepared to make some social sacrifices in order for that to happen. But I can only make that decision for myself, I have no right to make it for the World.

So from my standpoint the course we must follow is quite clear. We must have a broadly-based, detailed public inquiry into wilderness in BC. We must allow all sides to be heard. The input can be used to formulate a provincial wilderness policy for BC. Let the debate begin.

\title{
The Forester as Salesperson
}

by

\author{
Alex Dickson
}

Because people generally take the forest and its benefits for granted, they often fail to practice or support forestry when the opportunity presents itself. If this situation is to be remedied, the forester must learn to promote the forest's worth To do this, he must become a salesperson - a forest salesperson. And, to be an effective forest salesperson, he must use the combined skills of a public relations practitioner, communicator. sociologist and psychologist.

There are three factors which are common to successful selling:

1) The salesperson must be seen by the would-be buyer as honest and trustworthy. Development of that favourable image is the result of good Public Relations (PR).

2) He must be able to communicate effectively with the potential purchaser. This involves some knowledge of communication theory

3) He must be able to relate his product to the felt needs and interests of his customer. To do this, he has to know his product and something about "what makes people tick

Let us now look at each of these factors and determine how the forester might become more of the salesperson he needs to be.

\section{Public Relations}

First of all does a forester have public credibility? How do people see him? Is he perceived as a modern-day Paul Bunyon with muscles, double-bitted axe and a "foul mouth"? Is he seen as a tree planter or forest-fire lookout? Or, is he regarded as the professional, scientific college graduate he is?

The American Forest Institute, some years ago, found that foresters generally had an enviable reputation in terms of credibility. It would behoove them, however, to try to keep it that way by consciously observing some of the principles of good PR.

The whole purpose of PR is to relate effectively to people. This means that people have to know, understand and agree with what foresters do. At one time the barons of business declared that what they did was of no concern to anyone but themselves. Are foresters tending to take this same autocratic stand? Worse still are foresters the handmaidens of the modern-day "barons"? In our presen highly interdependent society, today's public opinion can be tomorrow's legislation. Therefore, the forester should be aware of how people see him and his role in society. (Bear in mind that he has an image whether he does anything about it or not.) If a "professional" does not show independence of thought he will not be accorded "professional respect".

The forester's character (actual situation) needs to match his reputation (how people perceive him). If it does not, then effort must be directed toward closing the gap. But it is not just necessary to do something whorthwile. The doing of that something must be brought to public attention. Now while it is true that "blowing one's own horn" is quite often considered reprehensible to modest people. not to do so - in the words of one PR textbook - is to ignore the "babble and bedlam in today's court of public opinion".
One simple definition of PR is: $P R$ is good work publicly appreciated. Another is: $P$ (for performance) $+R$ (for recognition) $=P R$. However, the one that appears to be most concisely appropriate is to be found in the 1978 edition of Cutlip and Center's Effective Public Relations:

Public relations is the planned effort to influence public opinion through good character and responsible performance, based upon mutually satisfactory two-way communication.

There are many examples of poor PR to be found in the annals of natural resources management. One that comes to mind concerns Dr. Bernhard E. Fernow who played an important part in the early development of forestry in Canada. While he was director of the first professional forestry school in the U.S. - Cornell University (1898-1903) - he antagonized his wealthy, influential Adirondack neighbours by clear-cutting, burning and planting in their northern New York playground. His proposition was to replace low-grade hardwoods with fast-growing conifers and, thus, substantially increase the yield. Time has vindicated his concept. However. because he didn't take the time to explain what he was doing to those around him, his intentions were misinterpreted and he ultimately lost his job. A sense of PR by Fernow could probably have prevented this from happening

Public relations is also common courtesy - a balance, if you like, in the Bank of Goodwill. It is most important that the withdrawals from that bank in terms of rudeness, mistakes and dishonesty, do not exceed the deposits in the form of good work done and recognized. When good 
credit has been built up in the Bank of Goodwill, it can be of tremendous benefit. Take, for example, the case of the housewife who goes to the grocery store and buys a baking mix. If the brand name is unknown to her a subsequent baking failure will be blamed on it. However, if she buys a wellknown brand, then any baking failure will be blamed on herself because of the credit that brand name has in the Bank of Goodwill. The forester, 100, must build up this kind of credit by being professional in what he does.

\section{Communication Theory}

In order to do a good job of conveying a message to his target audience, the forester needs to know something about the communication process. The goal of communication is to transfer facts, feelings and ideas from one person to another in such a way that the sender's intent is clear to the receiver and the receiver's response is clear to the sender.
Once the message is received it has to be internalized by the receiver (Decoding).

A common field of experience (terms of reference) is essential to meaningful encoding and decoding. Foresters run into this kind of situation when they are asked to explain forestry to lay people. Because foresters and lay people do not have knowledge of technical forestry jargon in common, terms such as dbh, basal area, live-crown ratio, form class and 2-2 transplants are meaningless without considerable explanation

Feedback is the mechanism by which the sender is informed of his success - or lack of it - in communicating with the receiver. In face-to-face situations, this could be a smile, a frown, a grimace or raised eyebrows. It could also be a "letter to the editor "in a journal which has published the sender's article. Frequently, mass media communication lacks feedback unless a special effort is made to obtain it.

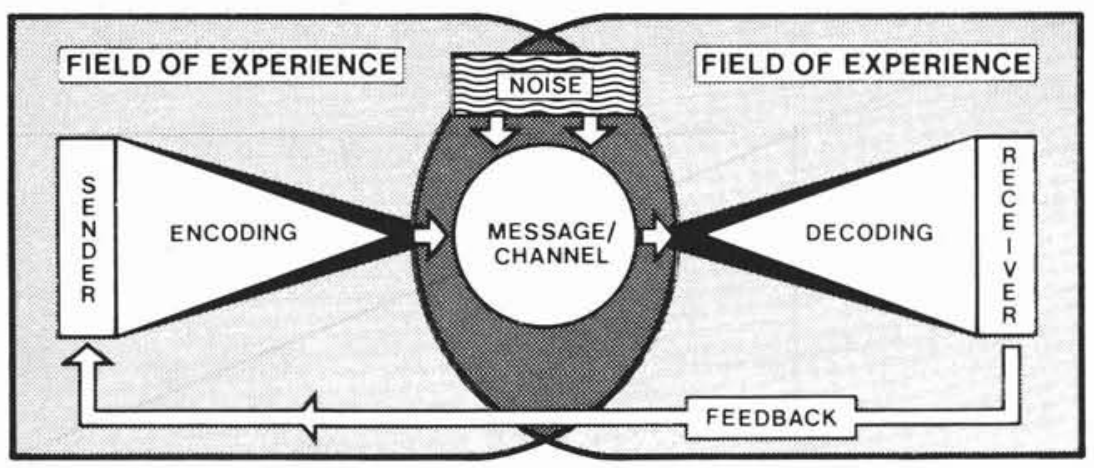

Figure 1 depicts a possible eight-element model of the communication process:

Before ideas in a person's head may be transferred to someone else's, those ideas have to be put into a form that can be transmitted (Encoding). Most often, this form involves the use of words, written or spoken. Frequently, too, these are supplemented by graphic or photographic images. Once the message is formulated the right channel (bridge connecting sender and receiver) has to be chosen. The channel might be a face-to-face conversation, a letter, an article, a TV or radio program, etc. The important thing here is that the channel should have the capability of effectively reaching the intended audience in a manner appropriate to the content of the message.
In the process of getting a message from the sender to a receiver, things happen that cause it to be distorted. These things are called "Noise". "Noise" is anything at all that constitutes a barrier to communication "Noise" can be just that - a physical effect on the eardrum that causes a distraction or drowns out the message. It can also be semantic: words meaning different things to different people. It can be an unfavourable predisposition of the receiver born of beliefs, prejudices, or certain socioeconomic factors.

Good communication only means that the message has been received and understood; it does not necessarily mean that the receiver will respond to the mes- sage in the desired manner. In other words, upon receipt of the message, he makes a judgement.

In persuasive communication, it is important to know something about the socalled Adoption Process. When people encounter a new idea, they go through a five-stage mental process before they adopt it into their daily routine. They first become aware. They then seek further information and evaluate it in terms of their own situation before trying and finally adopting it. At each stage in the sequence. too, different sources of information become important (Table 1).

Along with the adoption of new ideas. there is a Diffusion Process that carries these ideas throughout a social system. Within this system, people may be classified according to a time sequence in which they usually accept new ideas or practices. The distribution of adopters for any given idea follows a bell-shaped curve over time with the continuum of adoption divided into five categories. These categories, plus a summary of the adopter characteristics determined largely from agricultural studies, are shown in Table 2.

From the foregoing, it can be seen that, in any walk of life, there are those who adopt ideas faster than others. Such key people in the information network are known as opinion leaders and should somehow be involved in "spreading the word".

Communication, then, is the transfer of meaning from one person to another. To be effective in this the forester needs to know what he "means" and state it clearly. taking into account all possible barriers in his path. Moreover, once the message is received and understood, it begins to move through a social system to reach others. The skillful communicator identifies key people in the system with whom to communicate so that his message and associated action are adopted as quickly as possible

\section{Motivation - That Inner Drive}

There are four P's involved in innovation: purchase, patronage, pressure and persuasion. We have examples of all four in forestry. When subsidies are given to woodlot owners for tree planting, thinning or road building their time and effort are being purchased by society. When special tax concessions are made to forest landowners who are managing their properties. this is tantamount to patronage. When government decrees that certain forestry practices shall be applied and enacts appropriate legislation, that is pressure. When programs of educational, technica and marketing assistance are instituted. these amount to persuasion.

Table 1. Sources of information by adoption stage.

\begin{tabular}{llll}
\hline & \multicolumn{2}{c}{ Stage of Adoption } \\
\cline { 2 - 4 } Ranked Importance & Awareness/Interest & Evaluation/Trial & Adoption \\
\hline 1 & Mass Media & Friends and Neighbours & Based on self-satisfaction \\
2 & Friends and Neighbours & Government Agencies & with trial. Little outside \\
3 & Government Agencies & Dealers and Salesmen & influence. \\
4 & Dealers and Salesmen & Mass Media & \\
\hline
\end{tabular}




\begin{tabular}{|c|c|c|c|c|}
\hline $\begin{array}{l}\text { Adopter } \\
\text { Category }\end{array}$ & $\begin{array}{l}\text { Salient } \\
\text { Characteristics }\end{array}$ & $\begin{array}{l}\text { Personal } \\
\text { Characteristics }\end{array}$ & $\begin{array}{l}\text { Communications } \\
\text { Behaviour }\end{array}$ & $\begin{array}{l}\text { Social } \\
\text { Relationships }\end{array}$ \\
\hline $\begin{array}{l}\text { Innovators (First } \\
2.5 \% \text { to try out idea) }\end{array}$ & $\begin{array}{l}\text { "Venturesome": } \\
\text { willing to accept } \\
\text { risks }\end{array}$ & $\begin{array}{l}\text { Youngest age: } \\
\text { highest social } \\
\text { status; wealthy }\end{array}$ & $\begin{array}{l}\text { Closest contact with } \\
\text { scientific information } \\
\text { sources; relatively } \\
\text { greatest use of printed } \\
\text { information }\end{array}$ & $\begin{array}{l}\text { Some opinion } \\
\text { leadership }\end{array}$ \\
\hline $\begin{array}{l}\text { Early adopters } \\
\text { (Next } 13.5 \%)\end{array}$ & $\begin{array}{l}\text { "Respectable": } \\
\text { regarded by many } \\
\text { others in the social } \\
\text { system as a role- } \\
\text { model }\end{array}$ & High social status & $\begin{array}{l}\text { Greatest contact } \\
\text { with local } \\
\text { extension educators }\end{array}$ & $\begin{array}{l}\text { Greatest opinion } \\
\text { leadership of any } \\
\text { category in most } \\
\text { social systems }\end{array}$ \\
\hline $\begin{array}{l}\text { Early majority } \\
\text { (Next } 34 \% \text { ) }\end{array}$ & $\begin{array}{l}\text { "Deliberate": } \\
\text { willing to consider } \\
\text { innovations only } \\
\text { after peers have } \\
\text { adopted }\end{array}$ & $\begin{array}{l}\text { Above average } \\
\text { social status }\end{array}$ & $\begin{array}{l}\text { Considerable } \\
\text { contact with } \\
\text { extension educators } \\
\text { and early adopters }\end{array}$ & $\begin{array}{l}\text { Some opinion } \\
\text { leadership }\end{array}$ \\
\hline $\begin{array}{l}\text { Late majority } \\
\text { (Next } 34 \%)\end{array}$ & $\begin{array}{l}\text { "Skeptical": } \\
\text { overwhelming } \\
\text { pressure from peers } \\
\text { needed before } \\
\text { adoption occurs }\end{array}$ & $\begin{array}{l}\text { Below average } \\
\text { social status; } \\
\text { small income }\end{array}$ & $\begin{array}{l}\text { Secure ideas from } \\
\text { peers who are mainly } \\
\text { late majority or early } \\
\text { majority: less use of } \\
\text { mass media }\end{array}$ & $\begin{array}{l}\text { Little opinion } \\
\text { leadership }\end{array}$ \\
\hline $\begin{array}{l}\text { Laggards (Last } \\
16 \% \text { ) }\end{array}$ & $\begin{array}{l}\text { "Traditional"; } \\
\text { oriented to the past }\end{array}$ & $\begin{array}{l}\text { Lowest social } \\
\text { status; lowest } \\
\text { income; oldest }\end{array}$ & $\begin{array}{l}\text { Neighbors, friends: } \\
\text { and relatives with } \\
\text { similar values are } \\
\text { main information } \\
\text { source }\end{array}$ & $\begin{array}{l}\text { Very little opinion } \\
\text { leadership: } \\
\text { semi-isolates }\end{array}$ \\
\hline
\end{tabular}

Persuasion is the route we are most likely to follow - persuasion that is linked to human needs. Social scientists have long known that needs - especially needs that are recognized and felt by the individuals concerned - may act as powerful motivators. A need is defined as the gap between the status quo and a desired situation. To satisfy the need is to close the gap between what is and what ought to be. Thus, to be effective, persuasive communication has to be geared to the self-interest (needs) of the target audience.

There is a so-called hierarchy of needs in which two levels of needs are identified. Those on the lower level are concerned with such basic necessities as food, clothing, shelter, safety and security. Those on the upper level relate to group status (belonging), ego gratification, and selffulfillment. As a rule, lower-level needs must be satisfied before upper-level needs become operative as motivators. Also, money loses its motivational force as one climbs the "ladder" of needs.

At the lower level, many people want to save time, money, work, discomfort, worry, doubts and risks. At the upper level, they want to gain popularity, praise from others, self-confidence and prestige; or want to be up to date, creative, influential and efficient; or want to express their personalities, resist domination, satisfy their curiosity and improve themselves generally.

To sell forestry to someone, to which of these needs could the forester hitch his appeal? Could forestry, for example, be used to gain popularity or praise from others? The needs listed are by no means all-inclusive. They serve only to indicate the kinds of needs people have. In any given situation, an audience has to be analyzed and its specific needs identified to permit an appropriate appeal to be made.

The ideal supportive society from the forester's point of view is one that not only understands forestry principles but believes in what might be called a forestry ethic or code of correct conduct. Such an ethic has been shown to be associated with active forest management by woodlot owners, both in Europe and North America. It has been further shown that such an ethic is acquired early in life through such socializing influences as family, friends, school and youth groups. A person having this ethic considers himself a good steward of his forest resources, maintaining or improving them for future generations

We are dependent upon the forest for timber products and a variety of amenities. For many urban residents who take items on store shelves for granted, the role of the forest is not readily taken into account or valued. Hence, there is a great need to sell forestry to the public, as well as to the private woodlot owner who has opportunity to manage his own treed property.

\section{Be a Salesmaker}

In order for forestry to have the degree of understanding and support it merits, it has to be sold. Success will depend on credibility (which foresters already have to a large extent). It will also depend on delivery of timely messages to appropriate audiences in a way that relates to their needs and interests.

So, now, the challenge to foresters (and to their supporters) is to get out there and be salesmakers for forestry!

\section{Useful References}

Citizens Involved: Handle With Care! (A forest industry guide to working with the public). By Jean Mater, published by Timber Press, Forest Grove, Oregon, 1977

Effective Public Relations. By Scott $\mathrm{M}$. Cutlip and Allen $\mathrm{H}$. Center, published by Prentice-Hall, Inc.. Englewood Cliffs, New Jersey, 1978

Public Relations and Communications for Natural Resource Managers. By James R. Fazio and Douglas L. Gilbert, published by Kendall/Hunt Publishing Co., Dubuque, lowa, 1981. Selling Forestry. (A series for farm foresters.) By Eliot W. Zimmerman, published by USDA Forest Service. 1959. 